\title{
The effect of application of contextual teaching and learning (CTL) model-based on lesson study with mind mapping media to assess student learning outcomes on chemistry on colloid systems
}

\author{
Annisa Fadillah ${ }^{1}$, Ni Putu Laksmi Cintya Dewi ${ }^{2}$, Dimas Ridho ${ }^{3}$, Ahmad Nurkholis \\ Majid $^{4}$, Meidiana Nur Budi Prastiwi ${ }^{5}$ \\ ${ }^{1234}$ Chemistry Education Department of Post Graduate Program, Yogyakarta State University, \\ Yogyakarta, INDONESIA \\ ${ }^{1}$ Email: afadillah87@gmail.com
}

\begin{abstract}
The research was conducted to determine the effect of the application of CTL learning model based on lesson study with mind mapping media to the learning outcomes of students on colloid systems. The population of this research was all students of grade XI of SMA N 1 Sunggal. The sample was taken using on the purposive random sampling. The Experiment class was taught with Contextual Teaching and Learning (CTL) model based on Lesson Study with Mind Mapping media and the control class taught with conventional learning model. The data was collected using an objective test was consisting of 20 questions which validity, reliability, level of difficulty and power of difference had been tested. $\mathrm{T}$ test results showed that $t_{\text {calculate }}=2.1$ and $t_{\text {table }}=1.6697$ thus $t_{\text {calculate }}>t_{\text {table }}$ which means that $\mathrm{Ha}$ is accepted and Ho is rejected. The enhancement of the student learning outcomes showed that the results of experiment class are $\mathrm{g}=72.88 \%$, while the control class is $68.97 \%$. From the percentage, it can be seen that learning outcomes of the experiment class are greater than the control class. The analysis of developing cognitive aspects pointed out that $\mathrm{C} 1=70.02 \%, \mathrm{C} 2=73.58 \%, \mathrm{C} 3=68.63 \%$, Thus the domain of cognitive level are on the cognitive aspects of $\mathrm{C} 2$. The result of Lesson Study Analysis showed the results of $71.09 \%$ at the first lesson and $88.28 \%$ at the second lesson. It means that there is increasing adherence to the indicators after two lessons. Based on the above results, it can be concluded that the result of studying chemistry of the students of class XI of SMA Negeri I Sunggal TA 2014/2015 taught by a CTL model based on Lesson Study with Mind Mapping media was higher $(72.88 \%)$ than those taught by conventional learning models $(68.97 \%)$ in the subject matter of colloids System.
\end{abstract}

\section{Introduction}

Learning science, especially chemistry, is closely related to daily experiences. Chemistry is not a subject that is easily understood by the students because the concept is difficult and abstract[1]. Therefore, in the learning process, presentation of chemical materials need to be made interesting and fun so that students are understand such that they can understand the concept independently and can connect with real life. Chemistry curriculum that is based too strongly to the theory often ignore the human dimension and social, so it can cause the students to immediately give up to continue to study chemistry [2]. 
Contextual Teaching and Learning (CTL) is a conception of teaching and learning that helps teachers relate subject matter content to real world situations, and motivates students to make connections between knowledge and its application to their daily lives [3]. Contextual Teaching and Learning (CTL) aims to increase motivation of learners to take what they have learned and apply it, making it meaningful in the context of actions and interactions within their daily situations[4]. Also students learn through experience instead of memorizing. Remembering knowledge is not a set of facts and concepts are readily accepted but something to be constructed by the student [5]. Based on the results of previously conducted studies, learning through Contextual Teaching and Learning (CTL) models on the subject of colloids have influenced students' learning outcome on chemistry [6].

The aim of this study was to determine the learning result by teaching with Contextual Teaching and Learning (CTL) model based on Lesson Study with Mind Mapping and investigate the cognitive aspects of Taxonomy Bloom which the most developed method through the application of Contextual Teaching and Learning (CTL) model based on Lesson Study with Mind Mapping media on the subject of colloids system.

The Lesson Study start with 1) plan lessons through academic exploration of the teaching materials and teaching method; 2) conduct the teaching has planned by one teacher and other observer, invite colleagues to observe; 3) reflect on the last lesson through the exchange of views, reviews (reflecting, critiquing, and revising)[7], and discuss with the observers. In Lesson study, a group composed of three to five professional teachers usuallu with in the same grade level[8]. Therefore, the implementation of lesson study program needs to be monitored and evaluated so they will know how the effectiveness, efficiency and acquisition of the parties involved [9]. In addition, the pedagogical aspects can also be evaluated and identified with an aim to improve teaching[10]. Mind mapping was defined by Buzan as "an expression of radiant Thinking and is therefore a function of the human mind" and "a powerful graphic technique which provides a universal key to unlocking the potential of brain"[11]. According to Buzan mind mapping is different from concept mapping[12], students are able to visualize links between non-linear ideas, which in turn provides for creativity and meaningful learning[13]. Furthermore, mind mapping has been used to assess[14]. In research conducted by Dewi Nirmalasari on 'Comparative Study Used Mind Mapping and Crossword Puzzle media on Colloids' topic, student using Mind Mapping media have a better cognitive achievement than students with Crossword Puzzle media [15].

\section{Methods}

This research employed a quasi-experimental-control group design, involving pre and post test. This study involves the control and experiment groups. A pre-test was administered to the groups before treatment, to determine the group comparability. This research was conducted in SMA Negeri 1 Sunggal grade XI on January - June 2015 school year and the time of the study on the implementation of the learning process was 
the second semester of 2014 / 2015 academic year. The population in this study was all students of grade XI SMA Negeri 1 Sunggal class XI of 2014/2015 school year, consisting of 150 students of grade XI science and divided into four classes. The sample in this study was taken by purposive random sampling technique. The reason for using this technique was because each member of the population has an equal chance of being elected to be the sample. However, teachers were different for some classes, so that researchers deliberately chose classes that were taught by the same teacher for the possible conditions that being taught by the same teacher means that they have the same condition in learning. The sample consisted of 2 classes. First class used CTL(Contextual Teaching And Learning) model based on Lesson Study using Mind Mapping media, while the other class learned with conventional methods.

\subsection{Technique of Data Analysis}

Before conducting the study, instrument trial was first conducted, the research aims to determine the level of validity, level of difficulty, different test ability and reliability tests. Of the 40 questions that have been tested there were 20 questions deemed suitable for use and qualified. This research uses several techniques of data analysis, namely normality test, levene test, hypothesis test using one sample $t$ test and learning result improvement test (gain) which can be calculated by the formula:

$\mathrm{g}=\frac{\text { post test score }- \text { pre test score }}{\text { max score }- \text { pre test score }} x 100$

If the value of $\mathrm{g}<0.3=$ Low, $0.3<\mathrm{g}<0.7=$ Medium, $\mathrm{g}>0.7=$ High [16]. Then to determine the cognitive domain developed on each treatment is done by counting the number of each cognitive domains $(\mathrm{C} 1-\mathrm{C} 3)$ answered correctly on that class divided by the number of questions or by using the following formula:

$\mathrm{g}=\frac{\text { post test score-pre test score }}{\text { ideal max score-pre test score }} \times 100 \%$

Therefore, by using the above formula it will be visible which cognitive domains ( $\mathrm{C} 1$ - C3) develop from each different given treatment [17]. This study also analyzes the results of Lesson Study that is to determine the Percent of Improvement of each indicator which developed in each meeting, that is done by calculating the average of all indicators assessed by observers then the results are summed and divided by the number of observers or by using formula:

Mean Indicator $=\frac{\text { total score }}{\text { number of observers }}$.

Then after getting the average point of each indicator, so to determine the percentage increase in Lesson Study success can use the formula:

Lesson Study Percentage $=\frac{\text { Average Observer Score at Meeting }}{\text { Number of Observer }} \times 100 \%$.

Then from the formula it will be known the Lesson Study Percentage Results for each meeting. 


\section{Result and Discussion}

From the results obtained after the calculation, the average value of pre test, post test, standard deviation and student learning result improvement were received as in the following table:

Table 1. Average Learning Result

\begin{tabular}{|c|c|c|c|c|c|c|c|c|c|c|c|}
\hline \multicolumn{5}{|c|}{ EKSPERIMENTAL CLASS } & \multicolumn{5}{c|}{ CONTROL CLASS } \\
\hline \multicolumn{2}{|c|}{ PRETES } & \multicolumn{2}{|c|}{ POSTES } & \multicolumn{2}{c|}{ GAIN } & \multicolumn{2}{c|}{ PRETES } & \multicolumn{2}{c|}{ POSTES } & \multicolumn{2}{c|}{ GAIN } \\
\hline $\bar{X}$ & $\mathrm{~S}$ & $\bar{X}$ & $\mathrm{~S}$ & $\bar{X}$ & $\mathrm{~S}$ & $\bar{X}$ & $\mathrm{~S}$ & $\bar{X}$ & $\mathrm{~S}$ & $\bar{X}$ & $\mathrm{~S}$ \\
\hline 33 & 6,48 & 83 & 6,2 & 0,79 & 0,7 & 32 & 6,64 & 79 & 6,89 & 0,66 & 0,69 \\
\hline
\end{tabular}

From the table above it can be seen that there is a difference in the pre test and post test score of experimental class as compared to the control class that can be presented in the following picture:

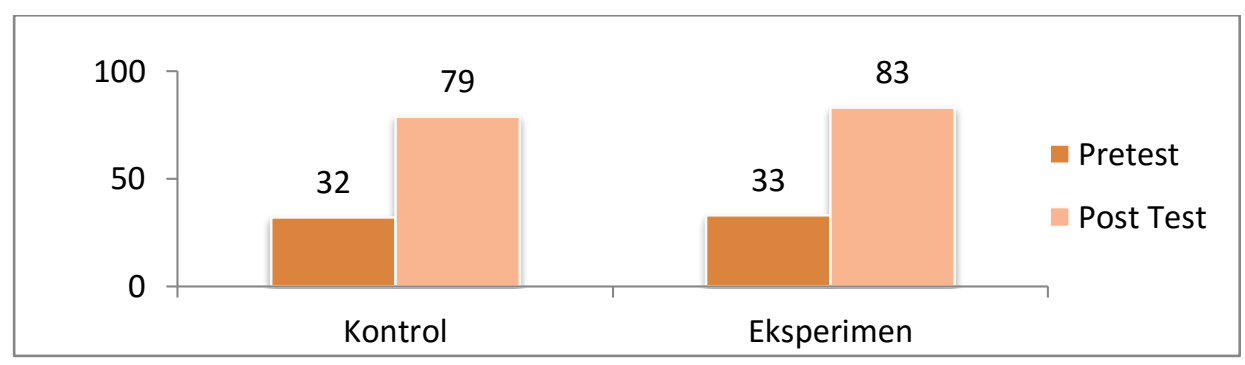

Figure 1. Learning Result of Experiment Class and Control Class

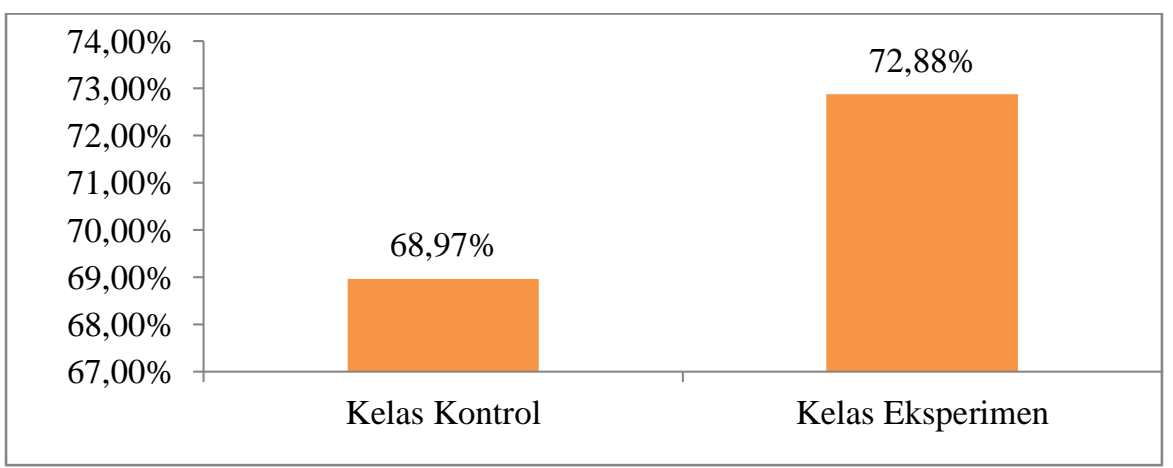

Figure 2. The Result Pretest and posttest of experiment Class and Control Class

From the pre-test result of experiment class, it was obtained an average score of 33. The posttest result of experiment class was an average score of 83 . The average score for control class's pretest result was 32, and the average score for control class's post test result was 79.The average score of gain of the experiment class was 0.73 with the average square deviation of 0.01 . Having in mind that both sample were of normal distribution and had the same variance or homogeneous, then it can be tested with t-test 
right side hypothesis test. This test is to determine whether or not this hypothesis is accepted. The criteria for testing is if the value of $t_{\text {count }>} t_{\text {table }}$ then Ha is accepted and $\mathrm{H}_{0}$ is rejected. From the calculations, the value of $t$ is: $t_{\text {count }}=2.1$ and $t_{\text {table }}=\mathbf{1 . 6 6 9 7}$ ) at $\mathrm{dk}=$ 66 at real level $\alpha=0.05$, ie 1.6697. Further the $t_{\text {count }}$ is consulted with the $t_{\text {table }}$ value, then $t_{\text {count }}>t_{\text {table }}(2.1>1.6697)$. This indicates that Ha is accepted that chemistry learning outcomes of students who apply learning models of Contextual Teaching And Learning (CTL) based on Lesson Study with Mind Mapping media is higher than the conventional learning model in the subject matter of Colloids Systems in class XI IPA at SMAN 1 Sunggal. To view the learning outcome of the chemistry of students in experiment class and control class is from the average normalized gain of experiment class and control class multiply with $100 \%$. The learning result improvement data of experiment class and control class is in the diagram below.

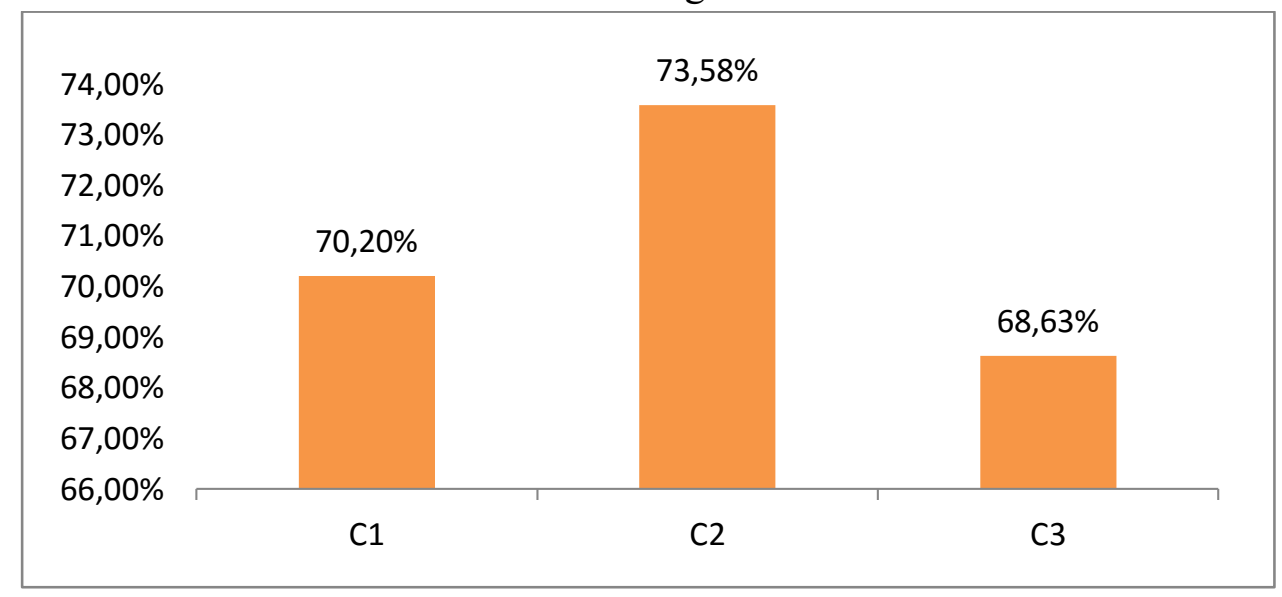

Figure 3. The Learning Result Improvement Percentage Of Experiment Class And Control Class

to determine the cognitive aspects developing from the class taught with Contextual Teaching and Learning model based on Lesson Study with Mind Mapping media, the gain is calculated for every aspect of cognitive used in the research (Appendix 24), starting from the level of knowledge $(\mathrm{C} 1)$, comprehension $(\mathrm{C} 2)$, and application (C3). The obtained data is as follows:

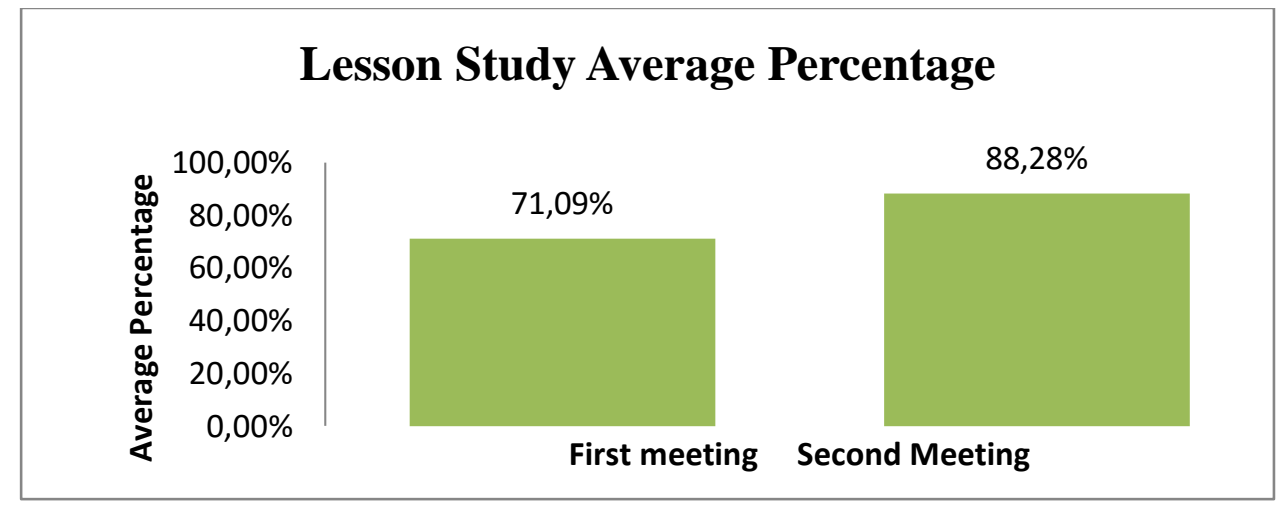

Figure 4. Percentage of Lesson Study Analysis Result 
To identify which Lesson Study develops in developing class experiment, the average for every aspect of the indicators used in the study is calculated. The analysis result from improvement data in experiment class can be seen in the following table:

Table 2. Results Mean Each - Each Lesson study Indicators

\begin{tabular}{|c|c|c|}
\hline Indicators & $\begin{array}{c}\text { Average score of } \\
\text { Meeting I }\end{array}$ & $\begin{array}{l}\text { Average score of } \\
\text { Meeting II }\end{array}$ \\
\hline Students forming a U-plan sitting & 93.75 & 100 \\
\hline students working together & 75 & 93,75 \\
\hline $\begin{array}{l}\text { students who do not understand / ask } \\
\text { to be taught }\end{array}$ & 87.5 & 81.25 \\
\hline $\begin{array}{l}\text { students who care and teach other } \\
\text { students }\end{array}$ & 62.5 & 75 \\
\hline Students drown in their own mind & 56.25 & 87.5 \\
\hline students listening more than talking & 56.25 & 87.5 \\
\hline $\begin{array}{l}\text { students maintaining motivation by } \\
\text { learning together }\end{array}$ & 62.5 & 87.5 \\
\hline Students utilizing media & 100 & 75 \\
\hline
\end{tabular}

Once the average of each indicator is known, the percentage of Lesson Study result at every meeting is determined. Lesson Study result average percentage can be seen in the diagram below:

\section{Discussion}

The implementation of Lesson Study based learning was known from student activity observation sheet which has been observed by the observers in the first and second meeting was $71.093 \%$ and $82.28 \%$. Furthermore, the cognitive gain expected that is $\mathrm{C} 2$ (understanding) with the result of $73.58 \%$ was in line with the CTL model constructing students' thought individually and as a group collaboration. The results of $\mathrm{C} 1$ cognitive (knowledge) amounted to $70.20 \%$, and the cognitive C3 (application) is 68.63\%. If seen the increase in cognitive aspects, it was $\mathrm{C} 2, \mathrm{C} 1$ and then $\mathrm{C} 3$. This cognitive percentage obtained from the number of students answering questions on the cognitive aspects of each $\mathrm{C} 1, \mathrm{C} 2$, and $\mathrm{C} 3$. The number of percentages of which cognitive aspects developed can be seen from the analysis of the question. To get good results the questions analysis should be distributed evenly to each indicator. This figure is some result of mind mapping of student that cause higer student achievment. 


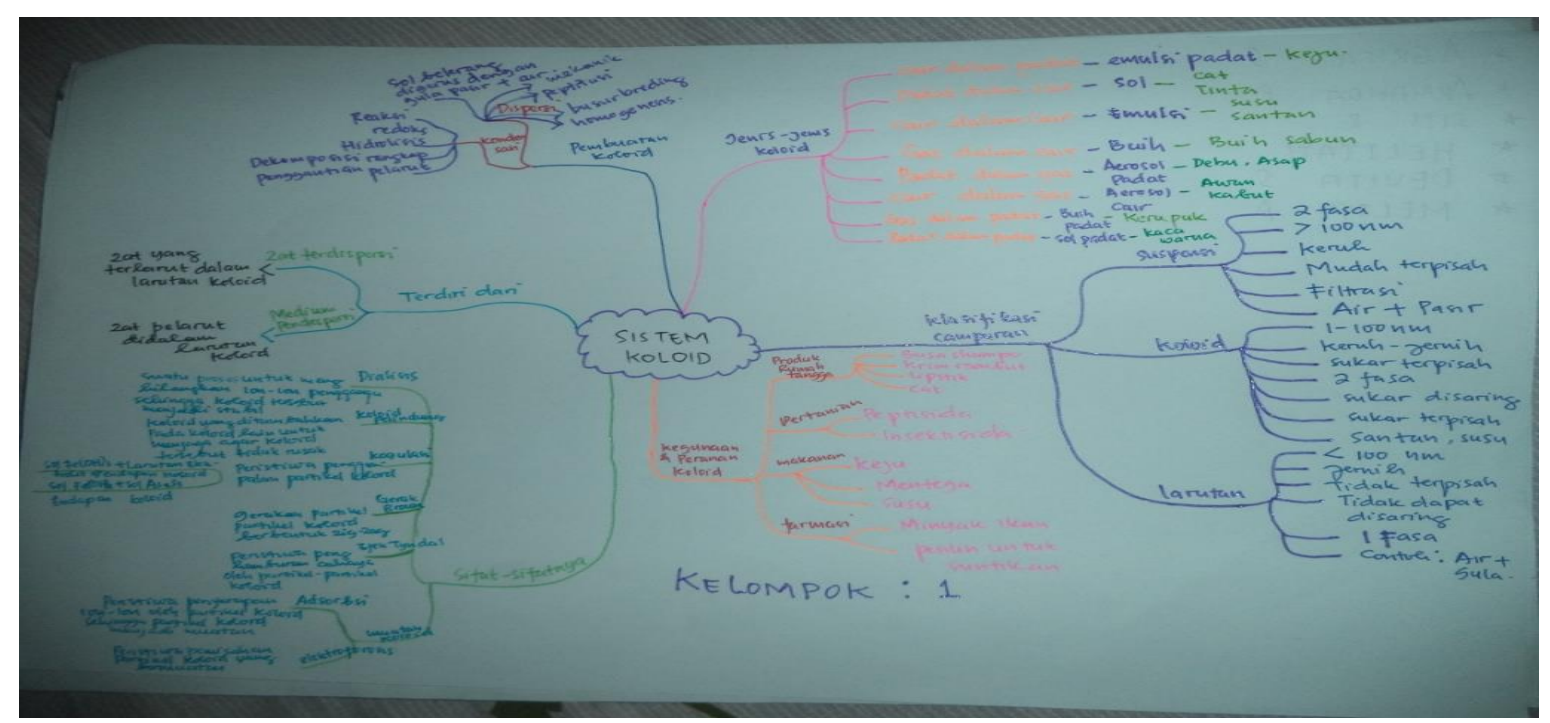

\section{Conclusion}

The learning out comes of student in experiment class is higher than the control class. The Gain of student in experiment class is 0,79 and in control class is 0,66 . The Lesson Study result increases at secong meeting which is $88,28 \%$. And the cognitive domain developed is the cognitive understanding domain (C2) that is $73,58 \%$.

\section{References}

[1] Stojanovska, Marina.I, et al, Addressing Misconception about the Particulate Nature of Matter among Secondary-School and High-School Students in Republic of Macedonia (2012), Creative Eduacation in Science Research, Vol.3, No.5

[2] Handayani, H., Pengaruh Pembelajaran Kooperatif Tipe Stad Dan Media Pembelajaran Terhadap Peningkatan Hasil Belajar Kimia Koloid Siswa Kelas XI SMA (2012), Skripsi, FMIPA UNIMED, MEDAN.

[3] Berns, Robert G., and Patricia M. Erickson., Contextual Teaching and Learning: Preparing Students For The New Economy (2001), The Highlight Zone Research@work.

[4] Ilhan, Nail et al., The Effect of Context-based Chemical Equilibrium on Grade 11 Students' Learning, Motivation and Contructivist Learning Environment (2016), International Journal of Environment \& Science Education, Vol. 11, No. 9

[5] Jauhari, M., Implementasi PAIKEM (2011), Prestasi Pustakaraya, Jakarta.

[6] Debora, S.N., Pengaruh Model Pembelajaran Contextual teaching And Learning (CTL) Terhadap Hasil Belajar Kimia Siswa Pada Pokok Bahasan Sistem Koloid Kelas XI SMA Methodist Lubuk Pakam T.A 2011/2012 (2012), Skripsi, FMIPA Unimed, Medan.

[7] Myers, Julia., Lesson Study as a Means for Facilitating Preservice Teacher Reflectivity (2012), International Journal for the Scholarship of Teaching and Learning, Vol.6, No.1 
[8] Gutierez, Sally Baricaua., Collaborative prefessional Learning Trough Lesson Study : Identifying the challenges of Inquiry-Based Teaching (2015), University of the philippines Diliman, Issues in Education Research.

[9] Warianto, Chaidar., Penerapan LessonStudy Berbasis Sekolah (2011), http://chaidarwarianto.guruindonesia. net/artikel_detail-28.html, diunduh $14 / 1 / 2015$.

[10] Iksan, Zanaton , et al., Applying the Principle of "Lesson Study" in Teaching Science (2014), Published by Cannadian Center of Science and Education, Vol.10, No.4.

[11] Liu, Ying, et al., The Effect of Mind Mapping on Teaching and Learning : MetaAnalysis(2014), Standard Journal of Education and Essay, Vol.2.

[12] Jones, Brett.D, et al., The Effect of Mind Mapping Activities on Student' Motivation (2012), International Journal for Scholarship of Teaching and Learning, Vol.6, No.1

[13] Long, Daniel, et al., Mind the Map: How Thingking Maps Affect Student Achievement (2011), An On-line Journal for Teacher Research, Vol.3, Issue 2.

[14] Adoho, S O., Effect of Mind-Mapping as a Self-Regulated Learning Strategy on Students' Achievement in Basic Science and Technology (2013), Mediteranian Journal of Science, Vol.4, No.6

[15] Nirmala, Sari Dewi., Studi Komparasi Penggunaan Media Mind Map Dan Crossword Puzzle Pada Metode Proyek Ditinjau Dari Kreativitas Siswa Terhadap Prestasi Belajar Pada Materi Pokok Sistem Koloid Kelas XI Semester Genap Sma N 1 Banyudono Tahun Pelajaran 2012/2013 (2013), Skripsi, FKIP UNS, SOLO.

[16] Tarigan, S., Pengantar Metode Penelitian Ilmiah (2011), Unimed, Medan.

[17] Al-Ayubi, Pane Salahuddin., Analisis Hasil Belajar Kimia Siswa Yang dibelajarkan Melalui Model Pembelajaran Kooperatif Tipe TGT Dan STAD Dengan Media Powerpoint Pada Pokok Bahasan Koloid Di Kelas XI IPA SMAN 3 Medan T.A 2013/2014 (2014), Skripsi, FMIPA, Medan. 